\title{
Cutting Characteristics of Aluminum Foil Stacked on Pressure Sensitive Adhesives Subjected to Two-Line Wedge Indentation
}

\author{
○学 大和田光宏（長岡技大・院） 正 永澤 茂（長岡技大） \\ 福澤 康（長岡技大）鈴木 茂和（福島高専）
}

\author{
Mitsuhiro OHWADA, NUT, 1603-1 Kamitomiokamachi, Nagaoka,Niigata \\ Shigeru NAGASAWA, ditto \\ Yasushi FUKUZAWA, ditto \\ Shigekazu SUZUKI, Fukushima national college of technology
}

Key words: shear, cutting, sheared profile, aluminum foil

\section{1. 緒言}

近年, 急速に普及しているスマートフォンなどのモバイル 端末やコンピュータ，携帯ゲーム機などの電子機器の筐体内 および液晶周辺には, 静電気対策と電磁シールドの目的で金 属䇴（アルミ及び銅）/糊/板紙構造体の粘着テープが使用さ れている。

また, 絶縁やスペーサーなどの用途としては樹脂/糊/板紙 構造体の粘着テープが使用されている. 電子機器などの高精 度化や微小化によって, これらのテープの加工には，より精 密できれいなものが要求されている.

しかし，これらは糊の上に金属箔や樹脂シートが載ってい るため, 製品として加工した際に糊のはみ出しや切断面のダ レなど糊の影響が問題となり，その加工条件は作業者のノウ 八ウによるものとなっている.

これらの構造体の加工条件について, 切断特性を評価し最 適な切断条件を検討することが必要である. そこで本研究で は, アルミ䇴 /糊 / 板紙構造体の加工特性と切断速度との関 係を実験的に解析した。

\section{2. 実験方法}

Fig. 1 に実験装置の概要を示す。試験片を面板上に上から 押さえた状態で固定し, 切刃を下降させ切断実験を行った.

試験片は, アルミ箔 $(0.08 \mathrm{~mm})$, 糊, 板紙 $(0.115 \mathrm{~mm})$ 力ら構 成されるシールド用片面粘着テープ AL7080 (試験片厚さ $t=0.2297 \mathrm{~mm}$ ) を長さ $40 \mathrm{~mm} \times$ 幅 $20 \mathrm{~mm}$ の矩形状に切り出 した.

切刃は，トムソン刃（刃先角度 $\alpha=42^{\circ}$ ）を用意し, 試験 片を切断した際に切刃に付着した糊の影響を無くすため, 実 験毎に刃部をアルコールで洗浄し糊を除去した。

切断速度 $V=0.025,0.05,0.1,0.2,0.3,0.4,0.5,0.6$,

$0.7,1.0 \mathrm{~mm} \cdot \mathrm{s}^{-1}$ の各々の速度で単位長さ当たりの押込み力 (線荷重) $f / \mathrm{N} \cdot \mathrm{mm}^{-1}$ と，切刃の押込み変位 $c$ を試験片の厚 さ $t / \mathrm{mm}$ で除した無次元押込み変位 $c / t$ を評価した.

各条件で 10 回の実験を行い，上層の箔が完全に切断され るまで切刃を押し込んだ，結果として $c / t<0.8$ まで切刃の定 速度押し込みを行った。

切断後, 試験片の切断面の様子を CCD カメラで観察し， 画像より切口断面の残留反り角度 $\theta \mathrm{w} /$ を測定した。

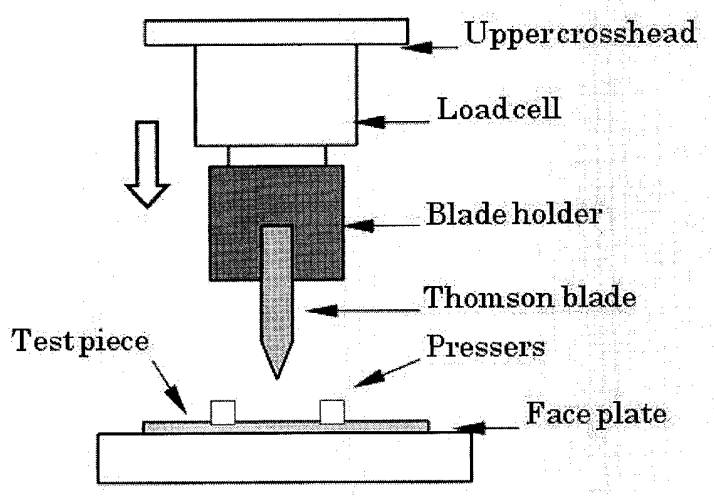

Fig.1 Schematic diagram of pushing test apparatus

\section{3. 実験結果と考察}

Fig.2 に切断速度 $V / \mathrm{mm} \cdot \mathrm{s}^{-1}$ を変えたときの荷重忘答を示 す. また, Fig.3に $V$ と単位長さ当たりの最大切断力（極大 線荷重） $f_{\text {peak }} / \mathrm{N} \cdot \mathrm{mm}^{-1}$ とその位置 $c_{\text {peak }} / t / \%$ との関係を示す.

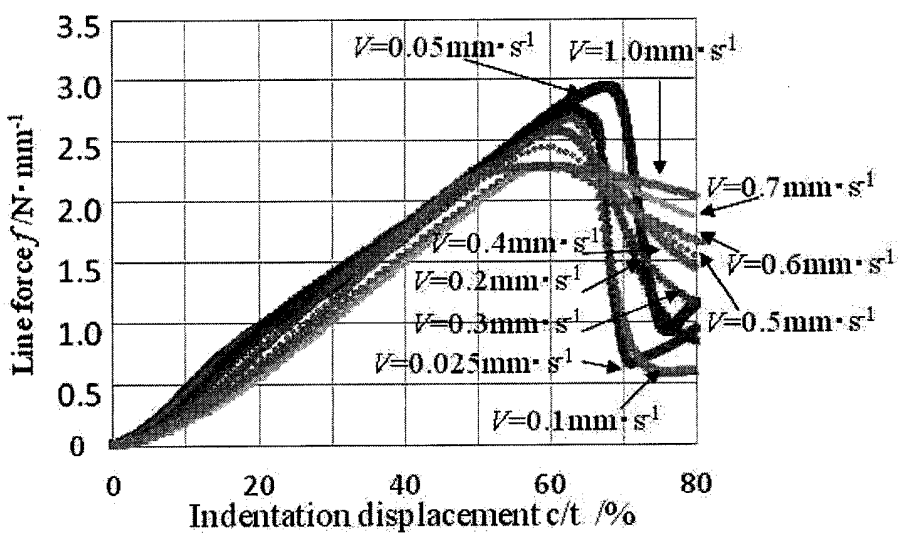

Fig.2 Relationship between cutting force and indentation displacement with respect to indentation (velocity) 


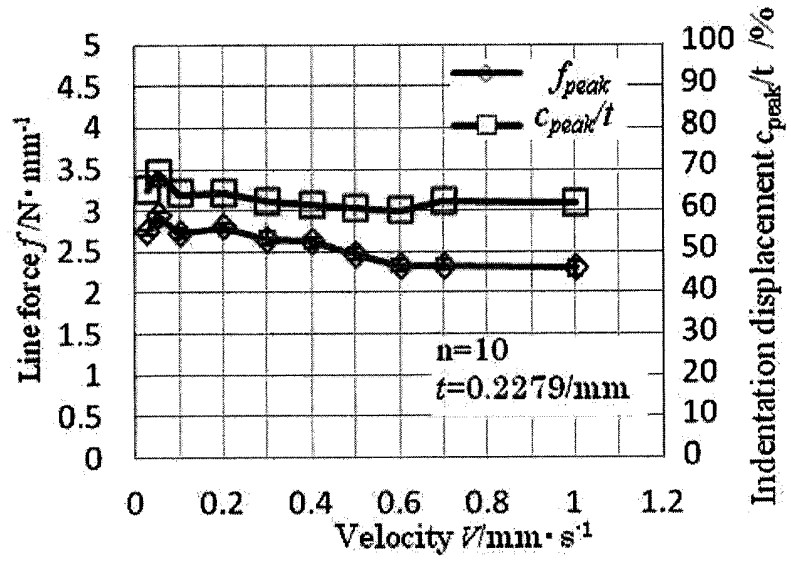

Fig.3 Relationship between line load peak and indentation $\mathrm{c}_{\text {peak }} / \mathrm{t}$ (samples numbers $\mathrm{n}=10$ )

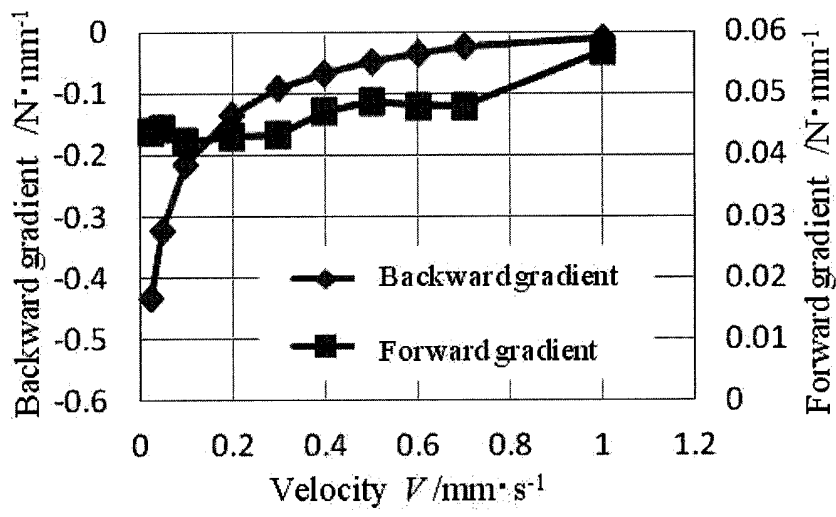

Fig.4 Relationship between velocity and gradient

Fig.2より, $V$ と荷重応答の関係では, 各々の切断速度に おいても荷重は，安定した立ち上がりとなっていることが分 かる.

しかし， $K<0.20 \mathrm{~mm} \times \mathrm{s}^{-1}$ では, $c / t=10 \sim 20 \%$ 荷重の変曲 点が見られる．この変曲点については， $c / t=10 \sim 20 \% の$ 值が 試験片の糊の厚さに相当するため, $V<0.20 \mathrm{~mm} \cdot \mathrm{s}^{-1}$ の低速域 では, 糊の変形が始まり潰れるまでの挙動が荷重応答に変曲 点として表れると考えられる。

Fig.3より，極大線荷重 $f_{\text {peak }}$ と $V$ の関係を見ると， $f_{\text {peak }}$ が Vの増加とともに減少する傾向が見られる。

しかし，曲的にうねる変動がある可能性があり，これにつ いては，Vの間隔をさらに小さくし分解能を上げて検証する 必要があると考える。

また, Fig.2より $f_{\text {peak }}$ 後の勾配の絶対值が $V$ とともに減少 傾向にあることが確認できる.この傾き $\partial f / \partial(\mathrm{c} / \mathrm{t}) / \mathrm{N} \cdot \mathrm{mm}^{-1}$ と $V$ の関係を Fig.4に示す. 極大点より前半の傾きについては, $c / t=20 \%$ から $f_{\text {peak }}$ の $90 \%$ 位置で計算を行い, 後半の傾きに ついては, $f_{\text {peak }}$ から最も $f か ゙$ 減少した位置で計算を行った.

結果より，Vの増加とともに勾配の絶対值が減少し，抵抗 が増加していることがわかる.この抵抗増加の要因として， 糊の流動が考えられるため今後さらに詳細な現象を追求す る必要がある。

応答全体の加工仕事を評価するため $\mathrm{Ec}=\int f \mathrm{~d}(\mathrm{c} / \mathrm{t})$ を求め

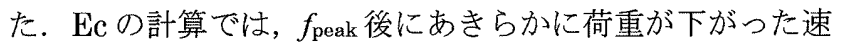
度域までを計算した。

その結果， $V$ に対してほぼ一定となった。このことから切 断仕事は，Vに対してほぼ一定である。

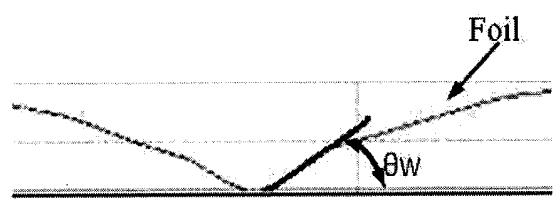

Fig.5 Measuring method of $\theta \mathrm{w}^{\circ}$

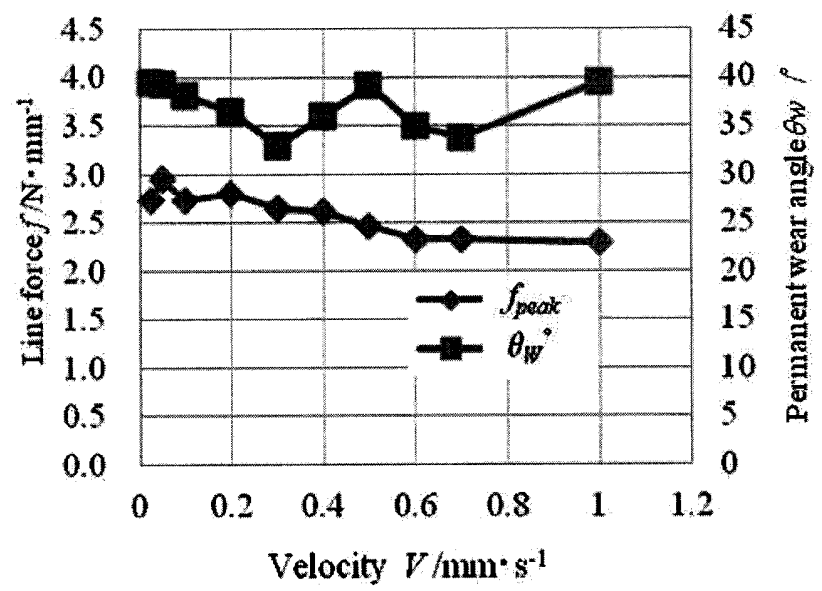

Fig.6 Relationship between cutting velocity and permanent wear angle $\theta \mathrm{w}$

切断面の切り口断面の残留反り角度 $\theta \mathrm{w}$ をイクロスコー プで撮影した画像から Fig.5に示す方法で測定し，その平均 とVとの関係をまとめたものを Fig.6に示す.

Fig.6より，V=0.3 mm* $\mathrm{s}^{-1}$ 付近で $\theta \mathrm{w}$ が極小傾向を呈す ると同時に, 荷重応答における極大破断後の減衰傾向が残存 する挙動へ遷移していることがわかる.

\section{4. 結言}

刃先角度 $\alpha=42^{\circ}$ のトムソン刃で，アルミ箔／糊／板紙か ら構成される構造体を切断速度 $V=0.025 \sim 1.0 \mathrm{~mm} \cdot \mathrm{s}^{-1}$ の範囲 で変化させて実験を行い, 切断線荷重 $f$ と切刃の押込み変位 $c / t$ との関係を解析した結果, 以下のことが明らかとなった.

（1） $V<0.20$ の低速域では， $c / t=10 \sim 20 \%$ で荷重の変曲点が 見られる. $c / t=15 \%$ 付近では糊の厚さに相当するから， 糊の変形が始まり潰れるまでの挙動が荷重応答に影響 を与えていると考えられる。

（2）極大線荷重 $f_{\text {peak }}$ と $V$ の関係を見ていくと, $f_{\text {peak }}$ が $V$ の 増加とともに減少する。しかし，低速領域ではうねる傾 向が見えるため, $V$ の間隔をさらに小さくし分解能を上 げて検証する必要があるとわかった。

(3) $f_{\text {peak }}$ 後の勾配の絶対值が $V$ 増加とともに減少すること から，抵抗が増加していることがわかる。この抵抗増加 の要因として，糊の流動抵抗が考えられる.

(4) $V=0.3 \mathrm{~mm} \cdot \mathrm{s}^{-1}$ 付近で残留反り角度 $\theta \mathrm{w}$ が極小傾向を呈 すると同時に, 荷重応答における極大破断後の減衰傾向 が残存する挙動へ遷移している.これより $\theta \mathrm{w}$ に対する 極大荷重後の残留減少の影響は顕著であると見受けら れる。

(5) $\theta \mathrm{w}$ の $V$ との依存関係が極在する傾向がある.今度さら に詳細な現象を追求する必要がある。

引用文献

1) ソニーケミカル\&インフォメーションデバイス株式会社, $\mathrm{http} / / /$ www.sonycid.jp /products/mc2/al 7080.html 